\title{
Förnekelsens grund
}

\section{Olov Wenell}

Hur många svenskar som emigrerade till Sovjetunionen och i synnerhet till Sovjetkarelen under 1920- och 1930-talen är inte helt klarlagt, men att det rör sig om mellan 500 och 1000 personer står klart vid det här laget. De flesta av dessa var kommunister och de flesta kom från Norrbotten med omnejd, varför de kommit att kallas "Kirunasvenskarna". De två viktigaste skälen för dessa människor att emigrera kan kortfattat sägas vara dels den dåliga arbetsmarknadssituationen i Sverige, dels drömmen om att få vara med och bygga världens första kommunistiska samhälle. Hur många som återemigrerade till Sverige är inte heller säkert, men utan tvivel rör det sig om merparten. Alla siffror rörande emigrationen är än så länge ganska osäkra. I och med att allt fler arkiv blir tillgängliga i Ryssland ökar kunskapen om antalet avrättade svenskar vilket, enligt uppgifter från den dåvarande säkerhetspolisens arkiv, nu är uppe i 35 personer. Ytterligare ett 50-tal svenskar blev med största sannolikhet mördade, men uppgifter om dessa saknas.

Anledningarna till att de återvände till Sverige berodde kort sagt på att levnadsförhållandena i många fall inte motsvarade förväntningarna. Ett viktigt skäl var naturligtvis de grymheter som de utsattes för av sovjetiska myndigheter, däribland NKVD, föregångaren till den mer kända KGB. De återvändandes berättelser och det faktum att de överhuvudtaget återvände gjorde att de mottogs med misstro av medlemmar och ledare inom kommunistpartiet i Norrbotten. Vittnesmålen om hot och allmänt misstroende är många. Till och med familjer och gammal vänskap splittrades på grund av att den bild återemigranterna förmedlade inte stämde överens med övriga partikamraters. Återemigranternas berättelser fördömdes av kommunisterna i Norrbotten och återemigranterna betraktades som lögnare och tystades ner. Varför? Att tvisten bottnar i politik torde stå klart, men vari ligger grunden till förnekelsen av de återvändandes berättelser om de faktiska förhållandena i det sovjetiska samhället och till att man har fortsatt att förneka trots att mer fakta allteftersom kommit i dagen? Till stor del har svaret sökts i den svenska inrikespolitiska situationen, men att se förnekelsen enbart som en del av denna är ett föga tillfredsställande förhållningssätt.

De som kommit att kritisera hemvändarna var trots allt inte sovjetmedborgare, utan svenskar, men var till stor del medlemmar av kommunistpartiet i Norrbotten. Förhållandet till sovjetstaten har varierat i omfattning och intensitet, men klart står att ledande kommunister i Norrbotten under 1920- och 1930-talet hade täta kontakter med sovjetiska företrädare. Även brev (censurerade av sovjetiska myndigheter) från svenska emigranter upprätthöll kontakterna mellan Norrbotten och sovjetstaten. Dessutom skrev tidningen Norrskensflamman flitigt artiklar om "Drömlandet" under den här perioden. Genom dessa kanaler tillgodosågs intresserade sympatisörer med information om Sovjetunionen, om hur ett kommunistiskt samhälle skulle se ut och hur man skulle bemöta "kapitalistiska fiender". Mycket av den här informationen stämde dåligt överens med de återvändande emigranternas berättelser. Under de här årtiondena torde således sovjetsympatisörernas uppfattning om de återvändande emigranterna uppstått och slagit rot.

Jag anser att en stor del av svaret på varför bemötandet av de återvändande emigranterna såg ut som det gjorde står att finna i det sovjetiska historiebruket och sovjetideologin. Att sovjetideologin på olika sätt presenterades för svenska sovjetsympatisörer är utom tvivel. Det sovjetiska historiebruket kom dem till del mer indirekt, genom exempel i tidningar och från ledande kommunistiska politiker om hur man handskas med historiska företeelser. Att lämna en analys av dessa två 
viktiga delar av sovjetsamhället därhän har tyvärr förekommit i alltför hög utsträckning i många arbeten som rör någon del av sovjetkommunismen. Hur såg då det sovjetiska historiebruket och sovjetideologin ut? Själva grundtanken i sovjetideologin, som vilade på en marxistisk grund, kan sammanfattas med att det endast fanns en "rätt" väg mot en kommunistisk framtid. De som inte ställde sig bakom denna gjorde, enligt ideologin, inte anspråk på sanningen, utan led istället av "falskt medvetande". Nära sammankopplat med detta var en "objektiv historisk nödvändighet", som rättfärdigade sovjetiska makthavares beslut och handlingar. I Sovjetunionen brännmärktes och förföljdes människor som inte följde den här vägen.

Vad det gäller det sovjetiska historiebruket så är det några punkter som är speciellt viktiga för förståelsen av hur den formade attityden mot de hemvändande emigranterna. Visserligen uppvisar historiebruket skillnader under sovjetepoken, men i olika grad var det dogmatiskt, såtillvida att odiskutabla fakta och inte de analytiska sambanden tillmättes den största betydelsen. Framträdande i historiebruket var även motsatser där historiska företeelser delades upp i gott och ont, svart och vitt och ställdes mot varandra, vilket inte lämnade någon plats för kompromisser. Dessutom kan historiebruket kategoriseras som allomfattande, där alla historiska företeelser inlemmades $\mathrm{i}$ en speciell tolkningsram där pluralism inte tilläts.

Det är inte svårt att se det nyss nämnda innehållet i sovjetideologin och historiebruket i överförd bemärkelse hur de svenska sovjetsympatisörerna bemötte de återvändande emigranterna och deras berättelser. Det tål att betonas att dessa punkter angående historiebruket och kärnan i sovjetideologin naturligtvis inte på något sätt rättfärdigar den omilda behandlingen av de återvändande emigranterna. Däremot ges här en ytterligare aspekt och förklaringsgrund, som jag menar är nödvändig i en beskrivning av företeelser som relaterar till sovjetkommunismen. Jag menar således att grunden till behandlingen av återvändande emigranter och deras berättelser inte står att finna i den svenska inrikespolitiska situationen, utan i sovjetideologin och det sovjetiska historiebruket. Detta resonemang kan tyckas självklart, men exemplen är många där de här viktiga aspekterna förbisetts. Den största anledningen till varför detta ignorerats torde vara att sovjetsystemet använts som ett slagträ i den politiska debatten, där resultatet av systemet varit av betydligt större intresse än dess grund. Det räcker således inte med att peka på felaktigheter, brister och orätter, (i det här fallet hos svenska sovjetsympatisörer), utan man bör samtidigt intressera sig för och analysera dess grund.

Det här problemet är näppeligen reserverat för just behandlingen av de återvändande svenska sovjetemigranterna. I studier med kopplingar till Sovjetunionen i allt från synen på historieförfalskning till bilden av andra världskriget måste sovjetideologin och dess historiebruk tas i beaktande. Utan ett sådant förhållningssätt får analyserna lätt en nedsättande och fördömande ton, vilket inte vidgar förståelsen.

\section{Referenser}

Eneberg, Kaa, 2003, Förnekelsens barn. Stockholm: Hjalmarson \& Högberg.

Eneberg, Kaa, 2000, Tvingade till tystnad. Stockholm: Hjalmarson \& Högberg.

Karlsson, Klas-Göran, 1999, Historia som vapen. Historiebruk och Sovjetunionens upplösning 1985-1995. Stockholm: Natur och Kultur. 